Francisco José Roma Paumgartten

\section{Long-term health benefits of appetite suppressants remain unproven}

\section{Benefícios dos inibidores de apetite à saúde a longo prazo permanecem sem comprovação}

\begin{abstract}
Because of the increasing prevalence of obesity, prevention and treatment of overweight has become a major public health concern. In addition to diet and exercise, drugs are needed for patients who failed to lose weight with behavioral treatment. The current article aimed to summarize recent concerns on the safety and efficacy of appetite suppressants. Several appetite suppressants have been banned for safety reasons. In 2010, sibutramine was withdrawn from the market because a long-term study showed it increased the risks of cardiovascular events. So far no study with a sufficiently large sample size has demonstrated that appetite suppressants can reduce morbidity and mortality associated with overweight. The withdrawal of sibutramine highlights that guidelines for the evaluation of weight control drugs must be more stringent, and studies on their long-term health benefits are needed prior to their marketing.
\end{abstract}

DESCRIPTORS: Appetite Depressants. Anti-Obesity Agents, adverse effects. Long-term Effect. Treatment Outcome. Obesity, prevention \& control. Sibutramine. Drug safety. Weight-loss drugs.

\section{RESUMO}

O aumento da prevalência da obesidade tornou a prevenção e tratamento do sobrepeso importante desafio para a Saúde Pública. Além da dieta e exercício, os medicamentos são necessários para pacientes que não conseguem perder peso com as mudanças comportamentais. O objetivo do artigo foi sumarizar as preocupações atuais com a segurança e efetividade de medicamentos inibidores do apetite. Vários anorexígenos foram banidos por razões de segurança. Em 2010, a sibutramina foi retirada do mercado porque um estudo de longa duração mostrou que ela aumentava o risco de eventos cardiovasculares. Até agora nenhum estudo com número expressivo de pacientes demonstrou que anorexígenos reduzem a morbi-mortalidade associada ao sobrepeso. A retirada da sibutramina do mercado mostra que diretrizes para avaliação de medicamentos anorexígenos devem ser mais rigorosas, e que estudos de longa duração sobre os benefícios para a saúde devem ser realizados antes da comercialização.

DESCRITORES: Depressores do Apetite. Agentes Anti-Obesidade, efeitos adversos. Efeitos a Longo Prazo. Resultado de Tratamento. Obesidade, prevenção \& controle. Sibutramina. Segurança de medicamentos. Tratamento da obesidade. 


\section{INTRODUCTION}

During recent decades the prevalence of overweight (body mass index - BMI $>25 \mathrm{~kg} / \mathrm{m}^{2}$ ) and obesity (BMI $>30 \mathrm{~kg} / \mathrm{m}^{2}$ ) has steadily increased worldwide. It was recently reported that $33.8 \%$ of adults ( $\geq 20$ years old) in the US, and $20 \%$ of adults in Europe are obese ${ }^{1, a}$ In Brazil, the prevalence of overweight and obesity have also soared, and a recent survey has estimated that nearly $50 \%$ of the population (all ages, males and females) are over the "ideal" weight and at least $13 \%$ are obese. ${ }^{\text {b }}$ Since overweight was shown to contribute to the development and aggravation of chronic conditions such as type 2 diabetes, hypertension, cardiovascular diseases, and several types of cancer, prevention and treatment of obesity is today a major public health concern. ${ }^{10}$

The current article aimed to summarize recent concerns on the safety and efficacy of appetite suppressants. In light of the recent withdrawal of sibutramine from the European and North American markets after being marketed for 13 years, it is emphasized that large controlled randomized clinical studies on long-term health benefits of anti-obesity drugs are required prior to marketing authorization.

\section{PHARMACOLOGICAL TREATMENT OF OBESITY}

The ultimate goal of any treatment of obesity is to prevent or mitigate morbid conditions associated with excess weight, and not only reduce weight or to achieve an "ideal" weight. Diet, exercise-based program and behavioral therapies are the first choice options for the treatment of obesity. According to modern clinical guidelines, pharmacological therapies, together with diet and exercise, should only be considered for obese patients who had failed to respond to behavioral approaches alone, and have no major contraindications to the use of the drug of choice. It has been recommended that drug treatment must be discontinued if the patient has a weight loss of less than $2 \mathrm{~kg}$ per month for the first three months of pharmacotherapy. ${ }^{8,11}$

In principle, both metabolic and behavioral components of body weight regulation are potential targets to pharmacology interventions, but anti-obesity drugs currently available include appetite suppressants and orlistat, an inhibitor of pancreatic lipase that decreases fat absorption in the gastrointestinal tract.

\section{FLAWS OF PAST ANTI-OBESITY DRUGS}

The search for an effective and safe pharmacological therapy for obesity has been so far frustrating. Many weight-loss drugs, mostly appetite suppressants, have been withdrawn from the market in the past for safety reasons. $^{2}$

The anorexic effects of amphetamines were found as early as the mid-1930s and amphetamine-like agents (e.g. dextroamphetamine, methamphetamine and others) became the first widely used drugs to induce weight loss. However, the effectiveness of sympathomimetic agents as anti-obesity drugs has been questionable at best. Central nervous system stimulant and anorexic effects of amphetamine-like drugs are apparently inseparable, tolerance develops over a few weeks, overall weight loss is only modest or unsatisfactory, and it is known they do not help to develop healthy eating habits. ${ }^{13}$ Because of they have high potential for abuse and addiction, and neuropsychiatric (psychotic symptoms, restlessness, insomnia, and others) and cardiovascular (hypertension, arrhythmias, angina and others) side effects, the use of amphetamine-like drugs for weight control was banned, drastically restricted or discouraged worldwide in the 1960s and 1970s. ${ }^{5,13}$

Fenfluramine and dexfenfluramine are inhibitors of serotonin reuptake and storage that were introduced as anorexic drugs in 1973 and 1985, respectively. Both drugs and a combination of fenfluramine and phentermine (known as "fen-phen") were widely used as weight-loss drugs until 1997 when they were withdrawn from the market in the US, Europe and other countries after reports of valvular heart damage, apparently caused by a selective stimulation of 5- $\mathrm{HT}_{2 \mathrm{~B}}$ receptors on human cardiac valves, and concerns on their possible association with pulmonary hypertension. ${ }^{2,3,5,9}$

Rimonabant, an endocannabinoid receptor (subtype CB1) blocker, received marketing approval from the European Medicines Agency (EMA) in June 2006 for treatment of obese or overweight (BMI $>27 \mathrm{~kg} /$ $\mathrm{m}^{2}$ ) patients with associated risk factors such as type 2 diabetes or dyslipidemia. In Brazil, where it was popularly known as "stomach fat pill," rimonabant was approved with similar indications in April 2007. It is noteworthy that the Brazilian Medicines Advisory Committee (CATEME) had recommended health authorities not to approve rimonabant marketing before clarifying concerns on an apparent drug-induced increased risk of depression. Shortly thereafter (June 2007), the US Food and Drug Administration (FDA) advisory committee voted not to recommend this drug's approval because of concerns of severe neuropsychiatric side effects. A reevaluation of safety data

\footnotetext{
${ }^{a}$ World Health Organization. Obesity. Geneva; 2011 [cited 2011 Mar 8]. Available from: www.euro.who.int/en/what-we-do/health-topics/ diseases-and-conditions/obesity

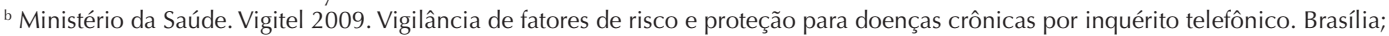
2010 [cited 2011 Mar 7]. (Série G. Estatística e Informação em Saúde). Available from: http://189.28.128.100/dab/docs/publicacoes/geral/ publicacao_vigitel_2009.pdf
} 
from rimonabant phase III studies showed that this CB1 blocker was associated with an increased risk of depression, anxiety and suicide ideation. ${ }^{3,5}$ Rimonabant marketing approval was withdrawn by EMA because they considered the risks outweighed the drug's benefits and, in the late 2008, the drug manufacturer announced that sales and clinical research studies of rimonabant would be stopped permanently worldwide. ${ }^{3}$

Benfluorex, a fenfluramine-derivative, was recently withdrawn (November 2009) from the market in France and other European, Asian and South American countries where it had been used since 1976 for treating patients with high blood levels of triglycerides and overweight plus type- 2 diabetes. A cohort study including a million patients with diabetes revealed that Benfluorex was significantly associated with hospitalization for valvular heart disease during the 2-year follow-up after drug exposure., ${ }^{9,12}$

\section{LONG-TERM SCOUT STUDY OF SIBUTRAMINE}

Sibutramine is an inhibitor of serotonin and norepinephrine (and to a lesser extent of dopamine) reuptake that was originally developed as an antidepressant and subsequently found to have anorexic properties as well. It was introduced into the market in 1997 at the time that fenfluramine-related drugs were removed from the market, and thus it largely replaced them as the most widely used appetite suppressants. Together with diet and exercise, sibutramine causes an average weight loss of $5 \%$ to $8 \%$, as compared with $2 \%$ to $4 \%$ achieved with placebo only. Similarly to other appetite suppressants, weight loss is more marked during the first weeks of sibutramine administration and patients regain approximately half of the weight lost when drug therapy is extended up to two years. Moreover, in almost all cases, the additional weight loss obtained with sibutramine is not maintained after drug treatment discontinuation.

Sibutramine treatment was shown to cause short-term reductions of LDL and triglycerides, but increases in diastolic blood pressure and pulse rates were found in at least two meta-analyses. ${ }^{4,7}$ One comparative clinical study also reported that, although inducing a reduction in body weight similar to that of orlistat in hypertensive patients, sibutramine did not exhibit the same beneficial effects on blood pressure. ${ }^{4}$ Almost a decade after drug marketing approval in the US and Europe, long-term cardiovascular safety and efficacy of sibutramine were examined in a clinical study (Sibutramine Cardiovascular Outcomes Trial - SCOUT). The SCOUT study involved 10,744 obese patients with preexisting cardiovascular disease, type 2 diabetes, or both. ${ }^{6}$ The results showed that sibutramine significantly increased (by 16\%) the risk of non-fatal myocardial infarction and stroke, although the study did not detect any changes in the incidence of cardiovascular deaths or deaths from any cause. ${ }^{6}$ The conclusions of the SCOUT study on cardiovascular outcomes were astonishing because pharmacological obesity treatment and any anti-obesity therapy are primarily intended to reduce morbidity and mortality associated with overweight. The results of the SCOUT study showed that, rather than reducing the risk, sibutramine in fact increased the risk of heart attack and stroke, and that treatment of obesity with this appetite suppressant was ineffective regarding cardiovascular outcomes.

Some physicians have argued that the SCOUT study investigated a particularly vulnerable subpopulation of obese patients with heart disease and/or type 2 diabetes, and that sibutramine would be safe for patients who did not have these comorbidities. However, these assumptions have not been challenged by any controlled study comparable in statistical power to the SCOUT study. Although there is certainly a higher risk for a subpopulation of obese individuals with preexisting comorbidities, asymptomatic patients and those who have undiagnosed cardiovascular diseases are at an increased risk as well. Overweight is a risk factor for cardiovascular disease and, in clinical practice, it can be difficult to reliably rule out patients with silent diseases who could be placed at risk with sibutramine. Nonetheless, the most important argument for recommending the withdrawal from market instead of a risk mitigation approach is the clear indication that sibutramine was ineffective in reducing overweight comorbidities. If a drug lacks efficacy, even a low risk seems unacceptable.

\section{REDUCTIONS IN MORBIDITY AND MORTALITY AS LONG-TERM EFFICACY VARIABLES FOR ANTI-OBESITY DRUGS}

Approximately 13 years passed before long-term clinical benefits of sibutramine were investigated by a post-marketing study involving a large number of subjects. If they were required by regulatory agencies for pre-marketing safety and efficacy evaluation, large long-term controlled randomized studies (the SCOUT study had a 5-year duration) would certainly increase drug research $\&$ development costs and considerably delay a decision on marketing authorization.

According to current guidelines (FDA, EMA) for developing weight control products (anti-obesity drugs), it is required a primary efficacy endpoint (phase III studies) of weight loss of at least $5 \%$ greater than placebo after a 12-month period. FDA additionally requires that the proportion of drug-treated subjects who lose $\geq 5 \%$ of baseline body weight is at least $35 \%$ and two-fold the percentage in the placebo group. EMA primary efficacy endpoint is more stringent and requires a weight loss of at least $10 \%$ of baseline weight over one 
year. ${ }^{c, d}$ Additional efficacy variables are the evaluation of effects of CNS-acting drugs on neuropsychiatric function, and lack of deleterious effects on cardiovascular risk factors (EMA). Both agencies recommend secondary endpoints for assessing efficacy such as blood pressure, pulse rate, lipids, fasting glucose, insulin, and EMA specifically recommends also ultrasensitive C-reactive protein, sleep apnea episodes, mechanical joint distress, infertility and psychosocial aspects (i.e., quality of life) ${ }^{\mathrm{c}, \mathrm{d}}$ Evaluation of long-term health benefits of anti-obesity drugs, however, is not currently required by regulatory agencies for marketing approval. The EMA guideline suggests that morbidity and mortality may be measured directly as efficacy variables, but points out that they can only be properly assessed in large clinical trials. ${ }^{\mathrm{c}}$

The short-term efficacy endpoints do not necessarily translate into long-term health benefits for overweight and obese patients. Sibutramine, for instance, met primary efficacy endpoint requirements in a premarketing phase III study, but it did not reduce cardiovascular morbidity in the long-term SCOUT study. ${ }^{6}$

One-year clinical data are insufficient to demonstrate that anti-obesity drugs are effective and safe for longer use. Obesity is a chronic condition and, since body weight lost with pharmacotherapy is generally regained after anti-obesity drug discontinuation, ${ }^{8}$ patients are expected to take these medicines for years, or even for the rest of their lives.

\section{CONCLUSIONS}

The regulatory agencies face a dilemma regarding guideline requirements for safety and efficacy of anti-obesity drugs. If guidelines are more stringent and evidence of long-term health benefits is required, manufacturers will have to deal with longer drug development timelines with higher costs, creating significant uncertainty on final approval for marketing. Today only one drug for long-term treatment of obesity (orlistat) is marketed in the US and Europe. Although there is a potentially huge and profitable market for this type of drug, much longer research \& development timelines and greater uncertainty on the outcome of drug approval process are likely to discourage investments in new anti-obesity medications. On the other side, if large clinical trials on long-term efficacy and safety are not required prior to marketing, new ineffective drugs, like sibutramine and other appetite suppressants, can be introduced into the market and be available for a long time.

\footnotetext{
c European Medicines Agency. Guideline on clinical evaluation of medicinal products used in weight control. London; 2007.

${ }^{\mathrm{d}}$ Food and Drug Administration. Guidance for industry: developing products for weight management. Rockville; 2007 [cited 2011 Mar 7]. Available from: http://www.fda.gov/downloads/Drugs/GuidanceComplianceRegulatorylnformation/Guidances/UCM071612.pdf
} 


\section{REFERENCES}

1. Flegal KM, Carroll MD, Ogden CL, Curtin LR. Prevalence and trends in obesity among US adults, 1999-2008. JAMA. 2010;303(3):235-41. DOI:10.1001/ jama.2009.2014

2. Glazer G. Long-term pharmacotherapy of obesity 2000: a review of efficacy and safety. Arch Intern Med. 2001;161(15):1814-24. DOI:10.1001/ archinte.161.15.1814

3. Heal DJ, Gosden J, Smith SL. Regulatory challenges for new drugs to treat obesity and comorbid metabolic disorders. Br J Clin Pharmacol. 2009;68(6):861-74. DOI:10.1111/j.1365-2125.2009.03549.x

4. Horvath K, Jeitler K, Siering U, Stich AK, Skipka G, Gratzer TW, et al. Long-term effects of weightreducing interventions in hypertensive patients: systematic review and meta-analysis. Arch Intern Med. 2008;168(6):571-80. DOI:10.1001/archinte.168.6.571

5. Ioannides-Demos LL, Piccenna L, McNeil JJ. Pharmacotherapies for obesity: past, current, and future therapies. J Obes. 2011;2011:DOI:10.1155/201 $1 / 179674$

6. James WP, Caterson ID, Coutinho W, Finer N, Van Gaal LF, Maggioni AP, et al. Effect of sibutramine on cardiovascular outcomes in overweight and obese subjects. N Engl / Med. 2010;363(10):905-17. DOI:10.1056/NEJMoa1003114

7. Johansson K, Sundström J, Neovius K, Rössner S, Neovius M. Long-term changes in blood pressure following orlistat and sibutramine treatment: a meta- analysis. Obes Rev. 2010;11(11):777-91. DOI:10.1111

j.1467-789X.2009.00693.x

8. Kaplan LM. Pharmacologic therapies for obesity. Gastroenterol Clin North Am. 2010;34(1):91-104. DOI:10.1016/j.gtc.2010.01.001

9. Le Ven F, Tribouilloy C, Habib G, Gueffet JP, Maréchaux S, Eicher JC, et al. Valvular heart disease associated with benfluorex therapy: results from the French multicentre registry. Eur / Echocardiogr. 2011;12(4):265-71. DOI:10.1093/ejechocard/jeq172

10. Li M, Cheung BM. Pharmacotherapy for obesity. $\mathrm{Br}$ J Clin Pharmacol. 2009;68(6):804-10. DOI:10.1111/ j.1365-2125.2009.03453.x

11. National Institutes of Health. Practical guide: identification, evaluation, and treatment of overweight and obesity in adults. Bethesda; 2000. (NIH Publication, 00-4084)

12. Weill A, Païta M, Tuppin P, Fagot JP, Neumann A, Simon D, et al. Benfluorex and valvular heart disease: a cohort study of a million people with diabetes mellitus. Pharmacoepidemiol Drug Saf. 2010;19(12):1256-62. DOI:10.1002/pds.2044

13. Weiner N. Noepinephrine, epinephrine, and the sympathomimetic amines. In: Gilman AG, Goodman LS, Rall TW, Murad F, editors. Goodman \& Gilman's The pharmacological basis of therapeutics. 6ed. New. York: Macmillan; 1980. p.138-75.

The author declares no conflicts of interests. 